\title{
Pastoral evaluation on the Basotho's view of sexuality: Revisiting the views on sexuality of Augustine, Thomas Aquinas, Martin Luther and John Calvin
}

\author{
Author: \\ David K. Semenya ${ }^{1}$ \\ Affiliation: \\ ${ }^{1}$ Unit for Reformed Theology, \\ North-West University, \\ Potchefstroom Campus, \\ South Africa \\ Correspondence to: \\ David Semenya \\ Note: \\ This article is published in the \\ section Practical Theology \\ of the Society for Practical \\ Theology in South Africa. \\ Email: \\ kwena@gkrandburg.org.za \\ Postal address: \\ PO Box 736, Fourways North \\ 2086, South Africa \\ Dates: \\ Received: 16 Apr. 2014 \\ Accepted: 04 Sept. 2014 \\ Published: 11 Mar. 2015 \\ How to cite this article: \\ Semenya, D.K., 2015, \\ 'Pastoral evaluation on the \\ Basotho's view of sexuality: \\ Revisiting the views on \\ sexuality of Augustine, \\ Thomas Aquinas, Martin \\ Luther and John Calvin', \\ HTS Teologiese Studies/ \\ Theological Studies 71(2), \\ Art. \#2689, 10 pages. \\ http://dx.doi.org/10.4102/ \\ hts.v71i2.2689

\section{Copyright:} \\ (C) 2015. The Authors. \\ Licensee: AOSIS \\ OpenJournals. This \\ work is licensed under \\ the Creative Commons \\ Attribution License.
}

\section{Read online:}

Scan this QR code with your smart phone or mobile device to read online.
This article examines the Basotho's views on sexuality within a theological context as well as the conflict between Christianity and cultural beliefs. Most Basotho have strong opinions on the subject of sexuality and those views undoubtedly emanate from the Basotho culture, which makes it necessary to evaluate them. The issue of sexuality is always a topic of discussion amongst people and did not go unnoticed by church fathers, like Augustine. Thomas Aquinas also expressed an interest in the topic in the Middle-Ages. Likewise, reformers of the calibre of Martin Luther and John Calvin espoused views on sexuality. It is clear that the aforementioned theologians made a marked contribution toward shaping the current views on sexuality, especially amongst theologians of this age and this is the reason for revisiting their views in this article examining the Basotho view on sexuality. In examining Basotho views on sexuality, the writer of this article will then discuss and evaluate the views of Augustine, Aquinas, Luther and Calvin with special reference to sexual intercourse, sexual intercourse within matrimony, extramarital sexual intercourse and also the unmarried state.

\section{Introduction}

It should be noted that to the Basotho ${ }^{1}$ it is taboo to speak of matters relating to sexuality in public or around children. Disobeying such a taboo is equal to disobeying the ancestors, in African culture the custodians of such beliefs and upholders of a tribe's well-being (Maleke 2014:48). The Basotho are, as an African people, also not exempted from obeying taboos and the customs set out by Africans throughout generations. The situation has, however, changed with the accessibility of information on any subject, including matters relating to sexuality, through the media and social networks. Körtner (2008:212) attests to this when saying that the attitudes regarding sexuality in our society are subject to a dramatic change. He does, however, add that changes in the field of sexuality, matrimony and family can only be theologically reflected in an adequate way if they are not immediately abstractly examined in terms of ethical viewpoints. Although there seems to be some change in people's views on sexuality, the writer concurs with the above statement that conclusions on the theological point of view should not be made from an ethical perspective only.

As Dreyer (2005:730) indicates, a vigorous debate about changing perspectives on sexuality is taking place in church circles in South Africa. Her statement is based on reports by the Nuus newspaper at the time, which prompted her to ask the question whether the perspective of the church regarding sexuality is still relevant or not.

On that note, Mashau (2011:7) emphasises that man is a sexual being who has the right to celebrate his sexuality. Louw (2009:94) affirms this by saying that sexuality touches the very fabric of human life and is part and parcel of being human, also functioning as an expression of human intimacy. The question, however, remains whether the Basotho's view on sexuality has a place within the theological spectrum. Regardless of the answer, it is the author's intention to provide more information regarding the issue of sexuality to provide the Basotho with a broader perspective to dealing with matters relating to sexuality.

1.Basotho refers to Tswana, Pedi and Southern Sotho nations of South Africa. The word Basotho is in the plural form whereas the singular form of the word Basotho is Mosotho. It is the writer's intention to make the reader aware that these nations may differ slightly in the way they define sexuality. However the essence of their views regarding sexuality is the same. For that reason the writer chose to incorporate the views of these nations in order to have a broader perspective of how in general they view their sexuality. 


\section{Discussion}

\section{The time of the church fathers and their view on sexuality (ca. 150-450 CE) - Augustine}

Although there were other church fathers ${ }^{2}$ who offered insight into the issue of sexuality, the author saw fit to focus on that of Augustine since the arguments of most other theologians, like Thomas Aquinas, developed from Augustine's stance on the matter.

Augustine believed that sexual intercourse was created good and as a natural part of God's order. However, this vision of sexuality did not exist in humanity's current sinful state. Man rejected God and chose to turn away from him. Although original sin was a sin of the soul and not a sin of the body, in punishment God allowed the body to rebel against the soul as the soul had rebelled against God. No longer could man control his body, particularly with respect to his sexual drive and members; it had taken on a life of its own and turned from the rational soul's control. Sexual concupiscence became the perfect illustration of original sin for Augustine, and the misuse of sexual intercourse was nothing more than a symptom of the ultimate turning away from God. Sex after the fall became the carrier of its own disordered desires of the flesh so that even procreative sexuality became suspect (Jungling 2007:321-322).

The above statement by Jungling (2007) would seem to suggest that Augustine was influenced by the state and world he lived in, as found in his Confession regarding his struggle with sexual concupiscence. It must be mentioned that Augustine also believed that there will be sexual activity even after the resurrection; a sentiment he later reconsidered, stating that the spiritual bodies of the resurrected will have biological sex, but no sexual intercourse which can only take place between mortal bodies. It should be understood that Augustine's change of mind about sexual activity after the resurrection only refers to a genitally organised, (potentially) reproductive, 'use' of the sexual organs, for which there would be no need in a state in which reproduction is unnecessary because death does not occur (cf. Miles 1988:347). The writer therefore concurs with what Miles has said regarding Augustine's statement that there will be no sexual activities and reproduction after the resurrection because death would not occur after the resurrection. In answering the Sadducee, Jesus Christ in Mark 12:18-27 stated: ' $[A] \mathrm{t}$ the resurrection people will neither marry nor given to marriage; they will be like the angels in heaven'. It should be noted that God created sex for married couples to enjoy and for procreation, so according to the writer there is no enjoyment other than being in the presence of the Lord; therefore sexual enjoyment in heaven is not necessary. Moreover, there will be no death in heaven so there is no need for reproduction since death will be at zero rate.

2.A church father by the name of Origen had himself castrated at an early age as part of dedicating his life only to God, because of his belief that one can only attain part of dedicating his life only to God, because of his belief that one can only attain
his rightful place in the presence of God if the sexual urge is totally eliminated his rightful place in the
(De Bruyn 1996:21-22).
Moreover, Miles (1988:348) says Augustine viewed sexual activity as merely scratching the itching scab of concupiscence, bringing little more than the satisfaction of a repetition compulsion. Certainly, Augustine's criteria for happiness were ambitious: intensity and permanence. Augustine added that in a way, sex is notoriously meeting one criterion at the expense of the other.

Cahill (2001:26) argues that Augustine was indeed quite undecided about sexual desire, although he did not condemn procreative sex in marriage. In contrast, De Bruyn (1996:22) argues that Augustine was of the view that sexual intercourse is essentially sinful, but still pardonable when it occurs within wedlock and with the exclusive aim of procreation. Moreover, De Bruyn (1996:23) adds that Augustine felt that even if it does take place within wedlock, it should not be motivated by desire and veniality which would make it sinful, albeit a pardonable sin.

Finn (2011:48-49) also argues that Augustine saw marriage as a beneficial social institution, necessary for the continuation of the human race and for the good of society as espoused in the traditional benefits of marriage. Instituted in Eden before the fall, marriage offered the three traditional benefits of mutual fidelity (fides), offspring (proles) and a sacred sign (sacramentum). Mutual fidelity, according to Augustine, is the commitment to have sex only with one's spouse, properly relieving what he considered the 'diseased state' (morbus) of sexual desire (concupiscentia); offspring is having and raising children, as a necessary condition for the bonding and friendly association of humankind (societas amicalis); and by a sacred sign he meant Christian marriage as a bond (vinculum) that signifies the indissoluble union between Christ and the church, described in Paul's letter to the Ephesians 5:32. On the other hand, Augustine argued that marriage serves to restrain and focus sexual desire, a dangerous and destructive human energy capable of tearing society apart - an argument he developed in the second controversy.

An analysis of the above insights into Augustine's stance seems to reflect a rather conservative view of sexual intercourse within marriage. In concurrence with De Bruyn (1996:22), it could be surmised that logically this view of Augustine leaves no room for extramarital intercourse. If intercourse within wedlock is already considered to be sinful, especially when practised for purpose of procreation, it would be an even greater sin if it occurred outside marriage. This, however, disqualifies any concept of practicing sexual intercourse when one is unmarried.

\section{The Middle-Ages (ca. 600-1400) - Thomas Aquinas}

Aquinas was no different from all his predecessors in the Christian church since the 2nd century. Aquinas's stance on sex is extremely negative, whereby sexual intercourse is inherently bad and sinful. The sin is, however, pardonable if it occurred for procreation and to prevent adultery - not 
by the person involved, but by the spouse. According to Aquinas, procreation is only possible through intercourse and as such a necessary evil. Intercourse is, however, not an essential, integral part of marriage (De Bruyn 1996:22-23).

Fullam (2012:676) states that Aquinas argued in the supplement to the Summa Theologiae 3 that since marriage is associated with sex and the loss of reason associated with sex, there must be some compensation, some 'goods which excuse marriage and make it right'. He then lists the three 'goods' Augustine identified, namely mutual fidelity (fides), offspring (proles) and a sacred sign (sacramentum). Aquinas prioritised the sacrament and specified that sacrament ranks first, because marriage without children and fidelity is still marriage, but not without the promise of permanence. He did, however, add that since the intention of procreation and the promise of fidelity is part of the marriage contract itself, these two elements of the contract are uppermost: first, offspring; second, fidelity; and third, sacrament. In the same work Aquinas, however, argued against polygamy on the grounds that marriage is a friendship and polygamy creates inequality in a marital friendship.

As outlined by Fullam (2012:676) in the latter part of his argument above, this shows that Aquinas did not support engaging in sexual activity outside matrimony or even when one is not married in any way. This reflects Aquinas's regard for marriage as part of a sacrament and sexual activity may not as such take place outside this sacrament.

It is important to remember that even if Aquinas viewed sexual activity within marriage as a pardonable sin, it still remains subject to a number of rules, especially for married Christians.

Milhaven (1977:158) mentions that Aquinas prohibited or discouraged sexual intercourse at certain times in the lives of Christian couples. Sexual relations render inappropriate the reception of the Eucharist on the following day. Neither would it be permissible on holy days, set aside for devotion to prayer, spiritual matters and for religious meditation or religious services or liturgy. These strictures coincide and differ in part in what is discouraged or forbidden, but Aquinas's reason for each stricture is the same: the nature of sexual pleasure. In man's fallen state resulting from original sin, sexual pleasure is not submissive to reason, but powerfully absorbing the mind and irresistibly distracts it from spiritual realities. Although conjugal sex is not generally sinful, the consequences of its pleasure make it unfitting during times set aside for spiritual activity.

Even though there are similarities between Augustine and Aquinas on the issue of sexuality, the difference in their views and adjurations becomes apparent in practical terms (De Bruyn 1996:23). This can be seen in Aquinas's rules for conjugal sex during certain religious activities, as recounted in the previous paragraph.

\section{Luther's view on sexuality Luther's view on sexual intercourse}

Luther espoused intercourse as an indispensable part of marriage, according to De Bruyn (1996:23-24), but like Augustine and Thomas he was convinced that sexual intercourse is essentially sinful. According to him, sexual intercourse is an inherent $\sin$ and could not ever occur without sin: it is the expression of wicked lust of a sinful nature. This leads to the conclusion that Luther regarded sexual intercourse as sinful, but pardonable within marriage.

Strohl (2008:138-139) explains that Luther emphasised the importance of marriage as a defence against lust, but it is only after the fall into sin that it acquires this prophylactic purpose. Moreover, Strohl (2008) quotes Luther as saying that:

In Paradise woman would have been a help for a duty only, but now she is also, and for the greater part at that, an antidote and a medicine; we can hardly speak of her without a feeling of shame, and surely we cannot make use of her without shame. (pp. 138-139)

Luther understood marriage as having a saving effect in this regard: it covers the rapacious and destructive drives of human sexuality with grace. It makes it possible to fulfil the natural longing for love, companionship and children. The force of destructive desire does not disappear, however, and Luther speaks sternly of the danger of lust vitiating the marital bond (Strohl 2008:138-139).

\section{Luther's view on sexual intercourse within matrimony}

Although Luther regarded sexual intercourse as sinful, he argued that:

God excuses it by His grace because the state of marriage is His work, and He preserves in and through the sin all the good which He has implanted and blessed in marriage. Through marriage, sex became a moral good, an expression of God's will. (Strohl 2008)

This is the heart of Luther's sexual revolution (Pelikan 1958:104-105). Moreover, according to Hendrix (2000:337), Luther rejected the sacramental character of marriage as depicted by Augustine and Aquinas.

According to Bell (2005:178), Luther argued that after the fall the place of sexuality and marriage changed. Adam met Eve in paradise still without any lust or sense of shame. If Eve had not sinned, she would not have given birth with pain and her union with her husband would also have been just as honourable (honesta). Adam would have known her with full confidence and an obedient will to God, without any evil thought. Nowadays the woman functions as a kind of medicine against sin, referring to 1 Corinthians 7:2. The writer agrees with Luther regarding the last statement that a woman serves as an antidote against men's lust. However the writer wants to add that not only man is to be found guilty in this part but both men and women are guilty since both of them have a lust because of the original sin, 
meaning that both of them serve as remedy to each other to satisfy their sinful lust. Luther also averred, in reference to a statement of Peter Lombard, how marriage in paradise was established as a duty (officium), but now it chiefly serves as an antidote (remedium). Men are, therefore, compelled to employ intercourse with their wives as a preventative measure to sin. According to Luther, there are very few who marry solely for the sake of duty and that for most people marriage is, of all things, a remedy to restrain lust. The role of sexuality has been changed drastically. After the fall, lust rages in men who are infected by the poison of the devil. Death has crept into all our perceptive powers, like leprosy, and nobody knows yet how much passion rules in the flesh. Bell, however, reminds the reader that according to Luther the fall was not the result of lust, but of disbelief on the side of a man (Bell 2005:178-179).

Buitendag (2007:455) defends marriage by saying that marriage as instituted by God should be regarded as sacred, forming an important tenet of his whole theology. It does not only serve to combat licentiousness, but is in truth also instituted by God (according to Luther's understanding, especially in terms of Gn 45:19 and 1 Cor 15:25.) It cannot merely be seen negatively as a 'remedy against sin', but also positively as the 'noblest and most precious work' and, even better, as the 'most religious state of all'.

According to Luther, as stated above, sexual intercourse is never without sin. Wedded couples are pardoned, however, since God would never consider their intercourse as impure or as $\sin$-despite the inherent sin tied up with it.

De Bruyn's (1996:24) analysis of Luther's view on sexual intercourse within matrimony describes the purpose of marriage after the fall as no longer just the union of a man and woman in a relationship of mutual support and procreation, but also as defiled by wicked lust. Now in post-fall times men and women desire each other not only for comradeship and for procreation - the purpose for which matrimony was instituted - but also to satisfy man's wicked lust, which is nearly as strong a motive. The result of that is obvious (which is tied up with marriage's third purpose), although pardoned if sexual intercourse occurs within wedlock.

\section{Luther's view on extramarital sexual intercourse}

Looking at the above views of Luther regarding sexual intercourse, one can only conclude that Luther regarded sexual intercourse as essentially sinful. Extramarital sexual intercourse would, therefore, undoubtedly also be sinful.

De Bruyn (1996:27) states that Luther irrefutably considered extramarital intercourse as against the law of God, subject to God's punishment. Extramarital intercourse completely disregards God and his commandments. Luther portrayed extramarital sexual intercourse as evil to the extent that whoever engages therein should be cast out from society for a period of time, to thereby atone for their offence and set an example to act as deterrent against such conduct
(De Bruyn 1996:27). The writer shares De Bruyn's sentiments regarding Luther's view of extramarital intercourse but adds that God never ordained extramarital affairs but ordained marriage itself which symbolises the relationship Christ has with his church (cf. Eph 5:32). Therefore the unfaithfulness in this regard is not condoned, meaning that married couples should be faithful as much as the church should be faithful to Christ. God used the word adulterer whenever Israel was going astray (cf. Is 57:3-10; Jer 2:9-26).

According to Ehesachen (1994), Luther went easy on engaged couples saying, 'To avoid offense, the betrothed should not yet live as married people. But any premature sexual intimacy between them, although reprehensible, should not be called fornication'. Secret intercourse of those who are engaged can certainly not be considered fornication, for it takes place in the name and with the intention of marriage a desire, intention or name which fornication does not have denoting the great difference between fornication and secret intercourse after the promise of marriage.

Luther regarded a woman's virginity as a valued possession that needs to be protected by refraining from sexual intercourse before marriage and as such a woman who has lost her virginity has lost her treasure. This is why Luther recommended that young people marry whilst still young. The highest age for a man to marry should be 20 years and for a woman between the ages of 15 and 18 (De Bruyn 1996:27).

There is indeed cause for arguing against Luther's stance on sexual activity in and outside of marriage. The author is of the view that Luther contradicted himself with his concession that engaged couples may engage in sexual activity, even though not yet married, and then averring sexual activities may only occur inside of wedlock.

\section{Luther's view on the unmarried state}

Ohlman (2011) relates how Luther once said that one should not regard any state as better in the sight of God than the state of marriage. In a worldly sense celibacy is probably better, since it has fewer cares and anxieties. This is true. Not for its own sake, however, but in order that the celibate may better be able to preach and care for God's Word, as Paul says in 1 Corinthians 7:32-34. It is God's Word and the preaching which make celibacy, such as that of Christ and of Paul, better than the state of marriage. In itself, however, the celibate life is far inferior.

Hobbs (2005:28-29) explains that Luther did not reject celibacy at all, but was reacting to the abuses of celibacy and the deprecation of marriage. He did not oppose celibacy per se, he honoured it. If he appears to oppose it, he does so only in the service of refuting scandalous practices. It is to this end that he aggressively refutes the idea of the superiority of the celibate and seeks to lift marriage out of its profane location and place it on the sacred plane beside or even above celibacy. Chastity is better to him, but if continence is impossible, one should marry. 
Witte Jr (2002) states that to Luther we are all sinful creatures and lust has pervaded the conscience of everyone. Marriage is not just an option; it is a necessity for sinful humanity. For without it, a person's distorted sexuality becomes a force capable of overthrowing the most devout conscience. A person is enticed by nature to concubinage, prostitution, masturbation, voyeurism and other sinful acts. According to Luther, 'You cannot be without a [spouse] and remain without $\sin$... To spurn marriage is to act against God's calling ... and against nature's urging'. Adding that the calling of marriage should be declined only by those who have received God's special gift of continence: 'Such persons are rare, not one in a thousand [later he said one hundred thousand] for they are a special miracle of God'. The Apostle Paul identified this group as the permanently impotent and the eunuchs; very few others can claim such a unique gift.

\section{Calvin's view on sexuality Calvin on sexual intercourse}

It should be noted that Calvin did not view marriage as a sacrament of the heavenly kingdom, unlike his counterparts Augustine and Aquinas. Calvin argued that though marriage symbolises the bond between Christ and his church, it does not confirm to any divine promise and does not confer sanctifying grace, as the true sacraments of baptism and the Eucharist do. Though it is a righteous mode of Christian living in the earthly kingdom, marriage has no bearing on one's salvation or eternal standing (Witte Jr 1998:17).

Though Calvin did not consider marriage a sacrament but instituted by God, just like Luther, he was convinced that intercourse is essentially sinful. However, if it occurs within matrimony, then it ceases to be sin (De Bruyn 1996:30).

As cited in Hobbs (2005), Calvin views marriage as the provision for the weakened human condition. Calvin also averred that the '... conjugal relation was ordained as a necessary means of preventing us from giving way to unbridled lust'. The truth is that 'natural feeling and the passions inflamed by the fall make the marriage tie doubly necessary, save in the case of those whom God has by special grace exempted'. Because complete, permanent self-control is rare, marriage is the remedy.

\section{Calvin's view on sexual intercourse within matrimony}

Calvin's early interest in marriage was mainly as a legal institution, useful for keeping order through contravening lust and, therefore, properly governed by the earthly magistrates (a perspective he shared with Martin Luther). Later, however, he became convinced of the need to explain marriage more theologically in order that Christians might approach it not merely as a civic duty, but as a calling. Calvin thus turned to the biblical theme of covenant - between God and Israel, between Christ and the church - as a means of stressing that marriage was not merely for the basic purpose of sex, but also for the equally important purposes of mutual love and support of spouses, as well as procreation and nurture of children (Blanchard 2007:227).

Even though sex in marriage is blessed by God, Calvin admonished married couples not to pollute it with uncontrolled and dissolute lust. Moreover, even if the honourableness of matrimony covers the wickedness of incontinence, it should not for that reason be a provocation to it. Therefore, even though there is the human tendency towards lust, Calvin called on married couples to enjoy sex 'soberly', modestly and moderately. Marriage is for satisfying lust, but not too much! Regarding the question of sexual purity, the main thing that recommends marriage (as opposed to celibacy) to Calvin, like Augustine, is its ability to keep otherwise lustfully wandering humans under control (cf. Blanchard 2007:229; De Bruyn 1996:32-33; Selderhuis 2009:460).

In discouraging imbalance in marriage, Baldwin (1991:142) relates how Calvin clearly emphasised that humankind, created male and female, is spiritually and sexually equal. This led the Geneva Consistory to treat men and women alike in matters of adultery and divorce. He also wrote and preached about the legitimacy of sexual union for a couple's bonding and joy. In numerous sermons, he gave guidance on ethical behaviour in marriage, condemning all forms of abuse and encouraging open communication on all levels between husbands and wives. Calvin also held social cohesion in great esteem, whereby couples seek their parents' blessing to marry. In this way marriage is not a personal choice, but regains a structural function (Hirzel \& Sallmann 2006:155).

According to Calvin, God commends modesty. Now, if the Lord requires modesty of man, then it means he condemns whoever opposes it. As a result:

[I]f one aspires to be obedient, let neither one's heart burn with wicked lust, nor one's eyes want only to run into corrupt desires, nor your body be bedecked with bawdy ornaments, nor your tongue seduce your mind to like thoughts with filthy words, nor your appetite inflame it with intemperance. All vices of this sort are like blemishes, which besmirch the purity of chastity. (Kerr 1989:69)

It is quite evident that Calvin opposed irresponsibility by wedded couples when it comes to sexual matters. Calvin envisaged married couples engaging in sexual activity with the intention of honouring God for this gift he gave them. The knowledge that God is watching over them creates awareness in the married couple that they should take care of the gift that God gave them, in this case sex.

\section{Calvin's view on extramarital sexual intercourse}

Calvin's view on extramarital sexual intercourse is rather easy to surmise, as De Bruyn (1996:32-33) finds, from Calvin's view on intercourse and marriage. If intercourse is essentially sinful, but marriage covers this sin before God, then extramarital intercourse is an uncovered and unpardonable sin in the eyes of the Lord. The people involved would stand accused and guilty before the judgement throne of God. 
In one of his Institutes of Christian Religion, Calvin (1997) argued that any mode of cohabitation outside of marriage is cursed in God's sight and that conjugal relations were ordained as a necessary means of preventing man from succumbing to unbridled lust. Humans need, therefore, to guard against yielding to indulgence in light of the assurance that the curse of God lies on every man and woman who cohabitates without being married.

This is a clear indication that Calvin only approved of sexual intercourse within marriage, unlike Luther who made a concession for engaged couples to have sexual intercourse given their intention to marry. De Bruyn (1996:33) adds that in prevention of adultery, Calvin warned engaged couples to not have sexual intercourse before their marriage has been consecrated in the church.

De Bruyn (1996:33-34) further explains that in Geneva, where Calvin was a pastor and a member of a consistory, premarital intercourse was forbidden; and both unmarried pregnant girls as well as women pregnant as a result of an extramarital affair were punished, made to beg for forgiveness in front of their congregation after Sunday services. The sexual activities of couples whose engagement had been blessed by the church were met with the same scorn as that of the adulterer (cf. Selderhuis 2009:460). De Bruyn (1996:33-34) adds that Calvin even went so far as to say that adultery should be punished by death (this view was, however, not implemented in Geneva).

\section{Calvin's view on the unmarried state}

According to Calvin, Hobbs (2005:19-20) states that only those who have been called to celibacy can seek God's assistance in abstaining from sex, a belief substantiated by Christ's words in Matthew 19:11-12 that not all are capable of being eunuchs for the sake of the kingdom. Paul, according to Calvin, makes the same claim in 1 Corinthians 7:7. This leads to Calvin's question: since chastity:

$\ldots$ is a special grace which the Lord bestows only on certain individuals, in order that they may be less encumbered in his service, do we not oppose God, and nature as constituted by him, if we do not accommodate our mode of life to the measure of our ability? (Calvin 1997:II; III; 41)

Without doubt, answered Calvin. Furthermore, the blessing of celibacy may be temporary. If at some point continence becomes impossible, marriage is an obligation. Paul orders in 1 Corinthians 7:9: 'If they cannot control themselves, they should marry'. Furthermore, this 'containing' refers not to the body only, but also to thoughts. Calvin concluded by reminding his readers that it is better to marry than to burn with lust.

Neither is celibacy an obligation of the earthly kingdom, according to Calvin: a celibate life is a 'special gift of God', commended only to those 'rare persons' that are continent by nature. It is the hypocrisy of demons to command celibacy and 'giddy levity' to exult the celibate state over the marital state. For the church to command celibacy is to 'contend against God' and to spurn his gracious 'remedy' for lust. The church subordinating marriage to celibacy is to commit the spiritual 'arrogance' of supplanting God's ordinance with a human tradition (Beaty \& Farley 1991:112; Witte Jr 1998:18).

\section{The Basotho's view on sexuality The Basotho's view on sexual intercourse}

With the above in mind, let us now analyse the Basotho's concept of sexuality. Nyirongo (1997:59-60) argues that Africans know about sin and understand that it was man's sin against God that made God withdraw to the sky. Whilst it is true that traditional and contemporary Africans have an awareness of original sin, the word sin has never been used by either traditional or contemporary Africans. Africans and in particular the Basotho use the word taboo for sin. According to the writer, Basotho refer to anything that is offending the community and the ancestors as moila (taboo). As mentioned in the introduction of this article, breaking a taboo is tantamount to disobeying the ancestors (the custodian of such beliefs and the sustainers of a tribe's wellbeing). A taboo is for them anything that is against their values and/or undermines their humanity. Groger (2011) further argues that the responsibility belongs to those who are physically alive, but more especially to the ancestral spirits who are the custodians of the community.

The Urantia Book (2014) explains that taboo is the source of ceremonial standards and the ancestor of primitive selfcontrol. It was the earliest form of societal regulation and for a long time the only one; it is still a basic unit of the social regulative structure. One can add by saying even amongst most of the Basotho of today, taboo serves as a basic unit of the social regulative structure in their lives. Most Basotho still refer to sinful behaviours as taboos, not sin, although they may use the two words interchangeably.

It is taboo for anyone to discuss sexuality in public or in the presence of children, but is also the responsibility of the parents to send their children upon puberty to the initiation school to receive instruction on matters of sexuality. Mudhovozi, Ramarumo and Sodi (2012) confirm the above statement that sexual socialisation is found in all South African ethnic groups and that this practice can also be found in other parts of Africa. In parts of East and Central Africa, traditional rituals of initiation prepare young people for adulthood including education on the responsibilities of sex, marriage and childbearing. Because sexuality contributes to social cohesion, communities developed 'rules' for the expression of sexuality as well as mechanisms for controlling sexual behaviour. Given that sexual activities have the potential to both cause harm, for example, sexually transmitted diseases, and good, communities developed codes of conduct relating to when, where and with whom sexual relationships might take place. These principles are communicated to young people through initiation ceremonies. 
According to Petchesky and Judd (1998), it would seem that parents are becoming increasingly reluctant to talk to young people about sex. This could be ascribed to parents' fear of encouraging sexual activity. Mothers often withhold important information about sexuality and reproduction from their daughters and instead impart messages of danger, fear and shame. Any discussion about sexuality is often limited to warnings about associated dangers and the importance of maintaining virginity for the preservation of honour. Many adults have difficulty recognising adolescents as sexual beings and as such adolescent sexuality is viewed as something that needs to be controlled.

Amadiume (2006) says in many traditional societies, initiation or marriage rituals teach young women how to physically prepare themselves for intercourse, including the use of rhythmic body movements that are enhanced by sounds and aids such as grass skirts, beads, body decorations, scents and incense, herbs and spices. Waist beads that previously conveyed the message 'do not touch' become sexual aids after marriage. The Basotho consider sexual intercourse meant for procreation to carry on the clan name. Begetting children guarantees continued existence. Not only do children provide for the reincarnation of the ancestors, but they also sustain the ancestors through prescribed rituals such as sacrifices and offerings (Turaki 1999:226). Children are regarded as the glory of marriage and the more children, the greater the glory (Waruta \& Kinoti 1994:91).

This undoubtedly confirms the notion that Basotho's purpose for sexual activities within marriage is procreation. The mere fact that children are sent to initiation schools for instruction on matters of sexuality is proof that Basotho parents want their children to learn more about their sexuality before they marry and reflects the Basotho's belief that sexual intercourse is to be confined to marriage.

\section{The Basotho's view on sexual intercourse within matrimony}

The above statements characterise sex as primarily intended for procreation and the sexual satisfaction of the husband. Initiation rituals do not emphasise mutual sexual pleasure, but the conception of children and sexual submission to the husband. The practice of genital mutilation of female initiates of the Basotho and also nations in other parts of Africa clearly promotes greater sexual satisfaction for the man than for the woman, since this ritual often includes the genital excision of female initiates (cf. Mbiti 1977:116; Semenya 2010:76).

In contrast, Amadiume (2006) argues that there is very little knowledge on the nature of sexual practices in Africa and we have as such labelled all women of the continent as sexually repressed, sexually inferior and sexually mutilated! Although sexual intercourse between married couples may occur frequently, there are times when it becomes taboo - for instance, when the wife is in her last month of pregnancy or before the child is weaned. During such periods the husband and wife are expected to resist adultery otherwise childbirth will be extremely difficult, impossible or even fatal to the wife.
There is what is called 'damage' within Basotho culture, and for Basotho the word damage explain this concept, from the writer's experience; any Mosotho boy who impregnates a girl is to pay 'damages'. Only the boy is punished in this case, whereas when both the girl and boy are found to be complicit in wrongdoing they are considered to have 'damaged' each other. Previously payment of such damages took the form of an animal, but in these modern times it is paid in money. Payment of such damages can, however, be avoided should the boy promise to marry the girl, which makes it clear that the Basotho believe sex to belong within marriage.

\section{The Basotho's view on extramarital sexual intercourse}

Looking at the discussions above, it is easy to conclude that extramarital intercourse is not permissible in Basotho society. Whoever engages in such activity, show disrespect to their families and the ancestors who blessed them with marriage.

Premarital sexual intercourse, including homosexual unions, incest, rape, seduction, intercourse with a 'forbidden relative' or an animal, intimacy between relatives and children looking at the genitals of their parents (in the widest sense of the word) all constitute sexual offences in any given community. Such offences are dealt with in a variety of ways. Africans are greatly sensitive to any departure from the accepted norm when it comes to sexual matters. This is a fundamentally religious attitude, since any of these offences upsets the equilibrium of the community - including the already departed. This is why these offences must be followed by a ritual cleansing, regardless of whether the offenders are physically punished or not, otherwise misfortune may ensue (Shorter 1998:95).

Mbiti (1977:35) continues in the same manner, arguing that sexual abuses like incest, homosexual relations, rape and adultery are abhorred by Africans. This leaves no room for extramarital sexual intercourse. Basotho do everything in their power to avoid extramarital affairs, which is why they practise polygamy and/or other forms of marriages like hlatswa dirope 3 [a male replacement marriage] and seyantlo ${ }^{4}$ [female replacement marriage] for the purpose of avoiding adultery and also in the name of bolstering their clan name (cf. Semenya 2010:91).

\section{Basotho's view on the unmarried state}

Semenya (2014:1) relates how marriage is one of the most important parts of Basotho life, a statement that leads to the conclusion that remaining unmarried is taboo for a Mosotho man or woman. An unmarried Mosotho is not welcomed by the community and at some social gatherings an unmarried individual cannot take part in certain social discussions. Even worse, such a person is unlikely to receive the status of ancestor upon death (cf. Maleke 2014:29).

\footnotetext{
3.The words hlatswa dirope [a male replacement] literally means a 'thigh cleaner' and refers to a brother of the deceased taking the place of his deceased brother by marrying his wife.

4.The word seyantlo [a female replacement] refers to a female who takes the place of
} her sister, when the latter has passed away and marries her husband. 
Moreover, Letšosa and De Klerk (2008) (as cited by Semenya 2014:1) explain that by remaining unmarried the Mosotho is setting his or her life in linear time and following a straight path that eliminates any possibility of returning as an ancestor and as such unable to be reincarnated through children. Marriage is considered the focal point of existence and is the point where all members of a given community meet the departed, the living and those yet to be born, thereby repeating, renewing and revitalising history.

Therefore, anybody who simply refuses to get married is committing a major offense in the eyes of society, which incurs ill-feeling from the community. In all African societies everything possible is done to prepare the young for marriage and centre their thoughts on marriage, which is why anything that deliberately aims towards the destruction or obstruction of human life is regarded as wicked and evil (Mbiti 1969:104).

\section{Evaluation of the views on sexuality of Augustine, Thomas Aquinas, Luther, Calvin and the Basotho}

The above discussions clearly reflect consensus amongst Augustine, Luther and Calvin on certain aspects of sexuality, that is, to all three sexual intercourse is sinful, but pardoned when practised within matrimony. The Basotho, however, diverges to a degree in that they have never used the word sin, but instead refer to such actions as taboo.

Luther, however, went so far as mentioning women as an antidote and a medicine to men's lust. Even though Basotho do not say that explicitly, one can in a way see that Basotho share the same sentiment with Luther regarding women as being remedies to satisfy men's lust. This can be traced by the way in which it is permissible for them to marry more than one woman. However it should be clear that it is not only the reason why Basotho do so: the other reason is to enlarge their clan name as depicted above in the article.

Furthermore, the Basotho give the gods and ancestral spirits much credit for the control of sexuality as is evident from the stipulations on the times that sexual intercourse is taboo. This equally conforms to Augustine's discouragement of sexual intercourse on certain occasions in the lives of Christian couples, like during the time of Eucharist, holy days and days set aside for religious meditation. Whereas for Basotho, married couples engaging in sexual activity becomes a taboo when the wife is in the final stages of pregnancy or before a child is weaned. There is, however, general agreement amongst Augustine, Aquinas, Luther, Calvin and the Basotho that sexual intercourse centres on companionship and procreation.

It also needs to be said that marriage has been instituted by God as a gift to every married couple. As indicated in Genesis 2, and as 1 Corinthians 7:9 exhorts, whoever is called to marry should do so, rather than burn with passion. There is, therefore, no doubt that sexual activity is linked to marriage and should be engaged in for the purposes of procreation and companionship. Calvin also emphasised, with reference to Hebrews 13:4, the importance of doing so in a responsible manner by not needlessly indulging in it.

Augustine and Aquinas, however, went further by saying that marriage should be regarded as sacrament. This is a sentiment with which Calvin disagreed, since in his view marriage symbolises the bond between Christ and his church and does not confirm any divine promise or confer any sanctifying grace as the true sacraments of baptism and the Eucharist do.

It should be noted that the view that sexual intercourse should be practised within matrimony advocated by Augustine, Aquinas, Luther, Calvin and the Basotho also includes instituting a kind of punishment when found to be guilty of such offence. However Kato (1975:41 as cited by Groger 2011) mentions that sin in the African worldview is against the community and not against God. In this instance it shows how Africans in their thinking have a strong element in connecting what is regarded as taboo to what can be called sinful. The idea that Africans as depicted by Kato still view sin as against their ancestors, not against God, clearly connects to the way most Africans view sin and taboo as the same thing and in most cases using the two words interchangeably. Moreover, Augustine argued that marriage serves to restrain and satisfy sexual desire, which is a dangerous and destructive human energy capable of tearing society apart - an argument he developed in the second controversy. One therefore would say that Basotho agree with Augustine because Basotho men would go as far as marrying more wives in order to restrain and satisfy their sexual desire.

Calvin went further in saying that even though the sin of sexual intercourse is pardoned within matrimony, it should not be defiled with false notions of inequality between men and women, that is, recognising that all men and women are spiritually and sexually equal. This principle is in complete contrast to the Basotho's belief that a wife should be submissive to her husband within the marital bed.

It is to be concluded from the above arguments of Augustine, Aquinas, Luther, Calvin and the Basotho that there is no place for extramarital sexual intercourse. The Basotho have introduced measures like polygamy and alternative forms of marriage to avoid adultery, practices which the Word of God rejects as wrong, as is clear from Genesis 2:18-25. The writer argues that these alternative forms of marriages like polygamy, seyantlo and hlatswa dirope should not be exploited as a means to avoid adultery, since these kinds of marriages are not in line with God's Word. Ephesians 5 is another example of the Bible's rejection of any form of extramarital sexual activity and anyone who engages in such deeds does it at his or her own peril.

Genesis 2:18; 21-24 further show that it is God who instituted marriage between a man and a woman and it 
was God who brought a woman to the man to be a husband and a wife. Therefore God does not do that in the form of the aforesaid types of marriages, because of the fact that man's will and purpose is placed first in these marriages. God is not pleased when man's will is placed above his, bearing in mind that marriage is God's institution and not man's.

Augustine explained his opposition to the unmarried state as the scratching of the itching scab of lust, since this state does not provide an outlet for man's lust. In this regard Luther's stance included the concession for engaged couples to engage in sexual activity, given the promise of their subsequent marriage. This view of Luther is not shared by Augustine, Aquinas, Calvin or the Basotho and is also in direct opposition to the Word of God, as is clear from 1 Corinthians 7:1-2 and 1 Thessalonians 4:3-4 that denote premarital sexual intercourse as sinful.

Although Luther did not reject a celibate life outright, he only considered it appropriate for those who have been granted this gift that should be used in service to the Lord. Luther's opposition thereto related to its practice by individuals not imbued with the gift to do so. Calvin was in full agreement with Luther in this regard and went even further by criticising the Roman church for forcing its priests and nuns to live celibate lives, terming it as a doctrine from the devil. The Basotho similarly oppose celibacy, considering it detrimental to fellowship within the community and the honour of returning as ancestor.

In terms of the latter statement, the writer avers that ancestors have no place in the institution of marriage and deserve no credit whatsoever. Neither are children born within wedlock to be considered blessings from ancestors, but rather blessings from God. Giving credit to ancestors in matters of human sexuality denies God his rightful role as author of human sexuality. A sin against human sexuality is a sin against God, not against ancestors.

\section{Conclusion}

This article set out to investigate whether the Basotho view on sexuality has any place in the theological spectrum. It is clear that the Basotho consider human sexuality as something to be respected and for that reason instituted a number of strict measures to prevent any abuse, which include measures like the payment of 'damage' by a boy or man who has impregnated an unmarried girl or woman and alternative forms of marriages, practiced to prevent adultery. This affirms that the Basotho indeed are clearly conscious that human sexuality should be respected.

It is evident that all these measures are carried out purely to appease the ancestors given that they believe the ancestors to be the custodians of their lives, including their sexuality. Although the measures put in place by the Basotho do serve the good of the community and its members, this approach to sexuality has no place in the theological context.
It is the duty of each and every Christian to endeavour to glorify God in all spheres of life, including their sexuality. One's lifestyle must conform to the Word of God, wherein pleasing God and not man or the ancestors is uppermost. The only way to please God is to know and follow what his Word says, including its teachings on matters relating to human sexuality.

\section{Acknowledgements Competing interests}

The author declares that he has no financial or personal relationship(s) that may have inappropriately influenced him in writing this article.

\section{References}

Amadiume, I., 2006, 'Sexuality, African religio-cultural traditions and modernity: expanding the lens', viewed 03 April 2014, from http:// www.arsrc.org/downloads/ features/amadiume

Baldwin, C.M., 1991, 'John Calvin and the ethics of gender relations', Calvin Theological Journal 26(1), 133-143.

Beaty, M. \& Farley, B.W., 1991, Calvin's ecclesiastical advice, John Knox Press, Westminster.

Bell, T.M.M.A.C., 2005, 'Adam and Eve in Luther's lectures on Genesis (135-1545)', Concordia Theological Quarterly 69(2), 160-184.

Blanchard, K.D., 2007, 'The gift of contraception: Calvin, Barth, and a lost protestant', Journal of the Society of Christian ethics 27(1), 225-249.

Buitendag, J., 2007, 'Marriage in the theology of Martin Luther-worldly yet sacred: an option between secularism and clericalism', HTS Teologiese Studies/Theological Studies 63(2), 445-461. http://dx.doi.org/10.4102/hts.v63i2.228

Cahill, L.S., 2001, 'Using Augustine in contemporary sexual ethics: A response to Gilbert Meilaender', Journal of Religious Ethics, Inc. 29(1), 25-33. http://dx.doi. org/10.1111/0384-9694.00064

Calvin, J., 1997, Institutes of the Christian religion, Logos Research Systems, Bellingham.

De Bruyn, P.J., 1996, Ethical perspective, Potchefstroom University for Christian Higher Education, Potchefstroom.

Dreyer, Y., 2005, 'Sexuality and shifting paradigms - setting the scene', HTS Teologiese Studies/Theological Studies 61(3), 729-751. http://dx.doi.org/10.4102/hts. v61i3.471

Ehesachen, V., 1994, Concerning matrimonial matters, A.D. 1530: What Luther says, Concordia Publishing House, Ewald MPlass.

Finn, T.M., 2011, 'Sex and marriage in the sentence of Peter Lombard', Theological Studies 72(1), 42-69. http://dx.doi.org/10.1177/004056391107200103

Fullam, L., 2012, 'Toward a virtue ethics of marriage: Augustine and Aquinas on friendship in marriage', Theological Studies 73(3), 664-692. http://dx.doi. org/10.1177/004056391207300309

Groger, K., 2011, 'How do African concepts of God relate to the God of the Bible?', viewed 30 July 2014, from http://www.rekindle.co.za/content/how-do-africanconcepts-god-related-bible

Hendrix, S., 2000, 'Luther on marriage', Lutheran Quarterly 14(3), 335-350.

Hirzel, M.E. \& Sallmann, M., 2009, John Calvin's impact on church and society, 15092009, Eerdmans, Grand Rapids.

Hobbs, R.J., 2005, 'Toward a Protestant theology of celibacy: Protestant thought in dialogue with John Paul II's theology of the body', PhD dissertation, Dept. of Religion, Baylor University.

Jungling, L.A., 2007, 'Passionate order: order and sexuality in Augustine's theology', Word and World 27(3), 315-324.

Kerr, H.T., 1989, Calvin's institutes: A new compend, Westminster/John Knox Press, Louisville.

Körtner, U.J., 2008, 'Sexuality and partnership: Aspects of theological ethics in the field of marriage, unmarried and homosexual couples', HTS Teologiese Studies/ Theological Studies 64(1), 209-225. http://dx.doi.org/10.4102/hts.v64i1.18

Louw, D.J., 2009, 'Human sexuality in an eschatological perspective: towards aesthetics of human embodiment and erotic sensuality in practical theology', Practical Theology in South Africa 24(1), 89-114.

Maleke, I., 2014, African spirituality, study guide DPT 125, Mukhanyo Theological College, Kwa Mhlanga.

Mashau, T.D., 2011, 'Cohabitation and premarital sex amongst Christian youth in South Africa today: A missional reflection', HTS Teologiese Studies/Theological Studies 67(2), Art. \#899, 7 pages.

Mbiti, J.S., 1969, African religions and philosophy, Heineman, London.

Mbiti, J.S., 1977, 'Christianity and African culture', Journal of Theology for Southern Africa 20(1), 26-40. 
Miles, M.R., 1988, 'Adam and Eve and Augustine: Christianity and crisis', viewed 03 April 2014, from http://www.theology.slu.edu/archive/progessays/cahall

Milhaven, J.G., 1977, 'Thomas Aquinas on sexual pleasure', Journal of Religious Ethics 5(2), 157-181.

Mudhovozi, P., Ramarumo, M. \& Sodi, T., 2012, 'Adolescent Sexuality and Culture: South African Mothers' Perspective', African Sociological Review 16(2), 119-138.

Nyirongo, L., 1997, The gods of Africa or the God of the Bible? The snares of African traditional religion in Biblical perspective, Potchefstroom University for Christian traditional religion in Biblical perspe
Higher Education, Potchefstroom.

Ohlman, V., 2011, 'What are you doing?: A conversation about dating and courtship', viewed 05 April 2014, from http://www.vonsbooks.com/home/theology

Pelikan, J., 1958, Luther's works volume 1: Lectures on Genesis chapters 1-5, Concordia Publishing House, Saint Louis.

Petchesky, R.P. \& Judd, K. (eds.), 1998, Negotiating reproductive rights: Women's perspectives across countries and cultures, Zed Books Ltd, London.

Selderhuis, H.J., 2009, The Calvin handbook, Eerdmans, Grand Rapids.

Semenya, D.K., 2010, 'A biblical framework for counselling as an alternative for traditional Sotho counselling on the life cycle', PhD thesis, North-West University, Potchefstroom.
Semenya, D.K., 2014, 'The practical guidelines on the impact of mahadi [bride price] on the young Basotho couples prior to marriage', HTS Teologiese Studies/ Theological Studies 70(3), Art. \#1362, 6 pages.

Shorter, A., 1998, African culture: An overview, Pauline's Publications, Nairobi.

Strohl, J.E., 2008, 'Marriage as discipleship: Luther's praise of marriage life', Dialog: A Journal of Theology 47(2), 136-142. http://dx.doi.org/10.1111/j.15406385.2008.00379.x

The Urantia Book, 2014, 'Sin, sacrifice and atonement', viewed 05 August 2014, from http://www.urantia.org/urantia-book-standardized/paper-89-sin-sacrifice-andatonement

Turaki, Y., 1999, Christianity and African gods: A method in theology, Potchefstroom University for Christian Higher Education, Potchefstroom.

Waruta, D.W. \& Kinoti, H.W., 1994, Pastoral care in Christianity: A challenge essays in pastoral theology, Acton Publishers, Nairobi.

Witte Jr J., 1998, 'Between sacrament and contract: marriage as covenant in John Calvin's Geneva', Calvin Theological Journal 33(7), 9-75.

Witte Jr J., 2002, 'The peril of celibacy: Clerical marriage and the protestant reformation', viewed on 04 April 2014, from http://cslr.law.emory.edu/ publications/publication/title/the-perils-of-celibacy-clerical-marriage-and-theprotestant-reformation/ 